\title{
ANALISIS NUMERIK BILAH KIPAS MESIN TURBOFAN TAY650-15 YANG MENGALAMI RETAK MENGGUNAKAN METODE ELEMEN HINGGA
}

\author{
Oleh: \\ Ade Irfansyah
}

Politeknik Penerbangan Surabaya

Jl. Jemur Andayani I, No. 73 Surabaya 60236

E-Mail: ade_irfansyah@dephub.go.id

\begin{abstract}
Abstrak
Faktor Intensitas Tegangan $(K)$ akibat adanya perambatan retak pada model bilah kipas mesin turbofan TAY 650-15 yang diperbaiki dengan teknik scallop dikaji secara komputasional. Perubahan harga $K$ terhadap panjang retak diamati untuk memprediksi umur sisa dari bilah kipas. Dari hasil simulasi diperoleh bahwa bilah kipas yang diperbaiki dengan teknik scallop yang melebihi kedalaman dalam SRM akan memiliki umur sisa yang jauh lebih pendek dari umur yang ditentukan oleh pabrik.
\end{abstract}

\begin{abstract}
The Stress Intensity Factor $(K)$ caused by crack growth at fan blade model of turbofan angine TAY 650-15 which repaired using scallop technique was investigated computationally. The alteration of the $K$ value toward crack length was axamined to predict the life limit of the fan blade. The simulation indicate that fan blade was repaired using scallop technique with depth exceeds the SRM restrictions would has life limit much shorter then life limit was given by manufacture.
\end{abstract}

Keywords: Finite Elemen Methods, Stress Intensity Faktor, Fatigue Life.

\section{PENDAHULUAN}

Jenis mesin yang banyak digunakan pada pesawat udara komersial adalah jenis mesin turbofan. Mesin turbofan merupakan salah satu jenis mesin turbin gas yang menggunakan udara sebagai fluida kerja, kemudian diproses untuk membangkitkan gaya dorong. Perbedaan mesin ini dengan jenis mesin turbin gas lainnya adalah penggunaan fan atau kipas sebagai low pressure compressor dan pembangkit gaya dorong (thrust). Penggunaan bilah kipas akan menurunkan efisiensi kerja jet sebagai pembangkit gaya dorong. Hal ini berdampak juga pada penurunan tingkat kebisingan yang ditimbulkan oleh semburan jet. Oleh karena itu mesin ini menjadi pilihan utama pesawat komersial berkecepatan high subsonic yang sangat memperhatikan kenyamanan penumpang. Bilah kipas berfungsi mengalirkan udara kedalam mesin, yang selanjutnya digunakan sebagai bahan pembakar yang dapat menghasilkan energi. Energi ini digunakan untuk memutar kipas turbin yang menghasilkan gaya dorong pada pesawat, juga digunakan sebagai pembangkit listrik. 
Dikarenakan fungsinya yang sangat penting didalam sistem power plant, maka bilah kipas harus dipastikan kondisinya tetap terjaga baik selama penerbangan berlangsung. Bilah kipas berada dibagian depan dari sistem, sehingga kondisinya bergantung dari beban-beban yang bekerja, dan juga akan bertumbukan dengan benda-benda yang mengalir bersama udara. Bilah kipas didesain dengan kriteria Safe Life, yang artinya bilah kipas tidak boleh mengalami kerusakan selama usia operasinya. Umur operasi untuk bilah kipas mesin TAY650-15 Rolls Royce menurut PT. NTP selaku perusahaan perawatan mesin pesawat udara, adalah sekitar 20.000 cycle. Dalam operasinya bilah kipas mengalami pengikisan dan tidak jarang menjadi cacat akibat tumbukan dengan benda-benda yang mengalir bersama udara. Jika hal ini tidak segera ditangani, maka bilah kipas akan patah dan juga akan menyebabkan kerusakan pada bagian yang lain dari mesin, seperti ditunjukkan dalam Gambar 1.

Kerusakan pada bilah kipas dapat diakibatkan oleh perambatan retak akibat beban fatigue. Parameter yang digunakan dalam menganalisis perambatan retak pada struktur adalah Faktor Intensitas Tegangan (Stress Intensity Factor, $K$ ). K didapatkan dari perhitungan Strain Energy Release $(G)$ yang digunakan untuk membuka permukaan retak terhadap modulus elastisitas material $(E)$. Sedangkan untuk mendapatkan $G$ diperlukan besarnya gaya dan perpindahan pada setiap nodal, dari hasil analisis Metode Elemen Hingga.

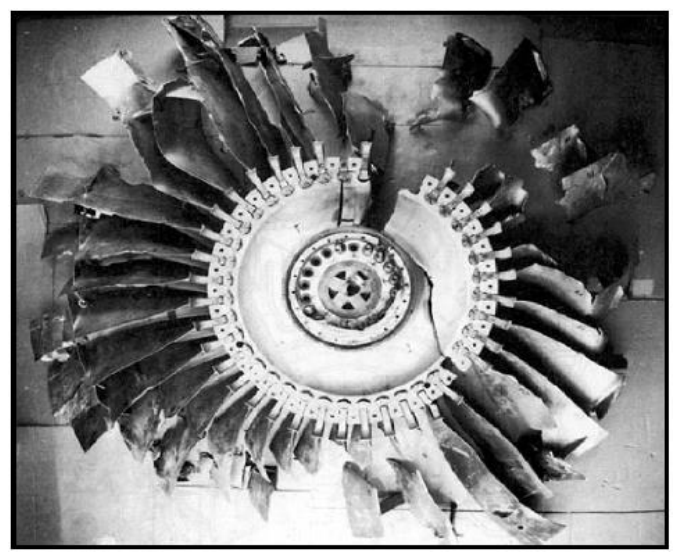

Gambar 1. Kerusakan pada bilah kipas

Bilah kipas yang mengalami retak dianalisis dengan menggunakan Metode Elemen Hingga. Pemodelan bilah kipas yang akan dianalisis adalah model bilah kipas 2D dan model solid 3D yang telah diperbaiki dengan teknik scallop.

Material yang digunakan dalam memodelkan bilah kipas adalah Titanium Alloy Ti6Al4V dengan modulus elastisitas $160 \mathrm{GPa}$. Nilai $K$ yang didapatkan bervariasi berdasarkan panjang retak $(a)$. Retak akan dimodelkan terus merambat dengan besaran $\Delta$ a hingga mencapai a kritis. Panjang retak kritis $\left(a_{c}\right)$ adalah panjang retak yang akan menyebabkan kegagalan pada struktur. Cara mendapatkan $\mathrm{a}_{\mathrm{c}}$ adalah dengan membandingkan nilak $K$ dengan nilai fracture toughness $\left(K_{c}\right)$. Jika nilai $\mathrm{K}$ sama dengan atau lebih besar dari nilai $\mathrm{K}_{\mathrm{c}}$ maka struktur akan gagal (patah).

Selain mendapatkan $\mathrm{a}_{\mathrm{c}}$ analisis ini dilanjutkan hingga mendapatkan umur sisa dari bilah kipas hingga mengalami kegagalan. Umur sisa dari bilah kipas dapat ditentukan dengan merujuk pada data hasil pengujian fatigue crack growth dari material titanium alloy jenis Ti6Al4V, yang dapat dilihat pada Gambar 2.

Terdapat beberapa kasus yang sering ditemukan dalam proses perawatan bilah kipas mesin turbofan. Ketika mesin beroperasi, terdapat partikel-partikel padat yang terhisap ke dalam mesin. Partikelpartikel ini bertumbukan dengan bilah kipas yang berputar. Salah satu akibat dari tumbukan partikel dengan bilah kipas ini adalah nicking. Nicking merupakan salah satu jenis cacat berupa notch yang terjadi pada bilah kipas. Daerah yang sering mengalami nicking adalah leading edge. 


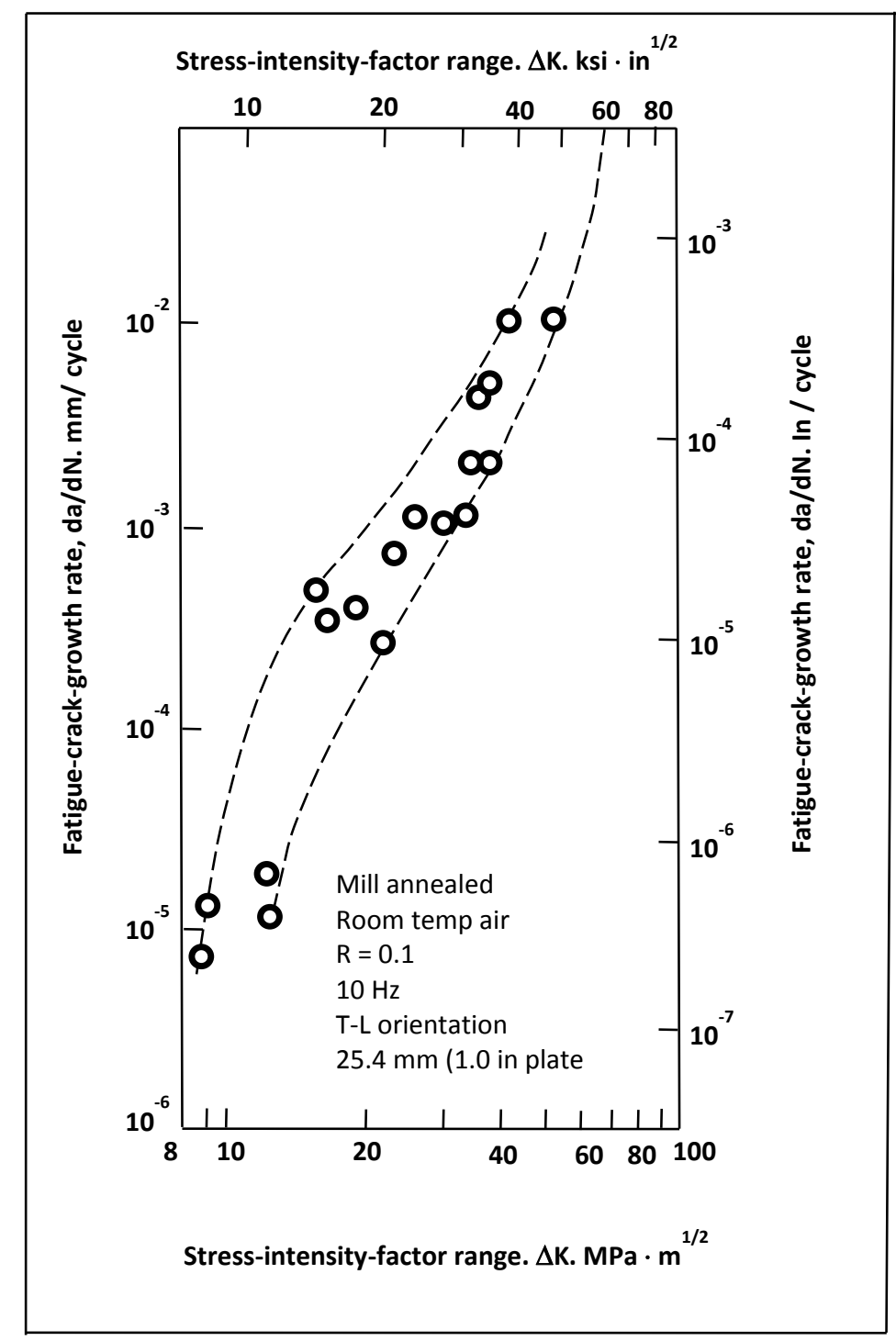

Gambar 2. Grafik hasil pengujiaa fatigue crack growth pada material Ti6Al-4V

Pada saat mesin beroperasi, bilah kipas akan menerima beban putar (rotation force) dan beban aerodinamika. Respon tegangan yang terjadi akibat pembebanan pada bilah kipas yang mengalami cacat berbeda dengan bilah kipas yang ideal (tidak terdapat cacat). Perbedaan tersebut adalah terjadinya fenomena konsentrasi tegangan pada bagian di sekitar nicking. Konsentrasi tegangan merupakan respon tegangan yang terdistribusi tidak seragam akibat adanya diskontinuitas geometri. Jika tingkat konsentrasi tegangan melebihi kekuatan material, secara teoritis bilah kipas akan mengalami kegagalan. Oleh karena itu perusahaan pembuat mesin menetapkan prosedur perbaikan untuk mengatasi cacat ini. Prosedur yang dilakukan dalam mengatasi cacat ini adalah scallop dan dressing. Scallop adalah pengikisan pada daerah yang mengalami cacat agar diskontinuitas geometri tidak terlalu tajam sehingga konsentrasi tegangan dapat dikurangi. Sedangkan dressing adalah pengikisan pada seluruh permukaan leading edge atau trailing edge sehingga chord dari bilah kipas akan berkurang. Scallop dan dressing ini memiliki batas toleransi ukuran yang diperbolehkan. Apabila batas toleransi ini sudah dilewati, maka bilah harus diganti dengan yang baru (discard). 


\section{PEMODELAN NUMERIK}

Bilah kipas mesin Turbofan TAY 650-15 memiliki panjang $400 \mathrm{~mm}$ dari pangkal penumpu hingga ujung tip bilah, serta memiliki lebar $180 \mathrm{~mm}$ dari leading edge hingga trailing edge. Tinggi bagian bilah kipas yang terkena aliran udara dari root ke tip adalah sekitar $380 \mathrm{~mm}$. Bagian ini memiliki luas permukaan sekitar $0.132 \mathrm{~m}^{2}$

Structural Repair Manual (SRM) tidak menyebutkan secara langsung jenis material yang digunakan sebagai bahan dasar bilah kipas kompresor pada mesin pesawat TAY 650-15. Namun dari keterangan PT. NTP material yang biasa digunakan adalah Ti6Al4V dan Nimonic-75. Material Ti6Al4V merupakan kelompok paduan alpha-beta Titanium yang menggunakan Aluminum dan Vanadium sebagai bahan paduan. Data material properties dari Titanium alloy jenis Ti6Al4V dapat dilihat pada Tabel 1.

Tabel 1. Data material properties Ti6Al4V

\begin{tabular}{|c|c|c|c|c|c|}
\hline$(\mathbf{E})$ & $(\boldsymbol{\rho})$ & $\mathbf{( v )}$ & $\left(\boldsymbol{\sigma}_{\mathbf{y}}\right)$ & $\left.\boldsymbol{(}_{\text {ult }}\right)$ & $\left.\mathbf{( K}_{\mathbf{I C}}\right)$ \\
\hline $\begin{array}{c}160 \\
\mathrm{GP} \\
\mathrm{a}\end{array}$ & $\begin{array}{c}4144 \\
\mathrm{~kg} /\end{array}$ & 0.3 & $\begin{array}{c}825 \\
\mathrm{~m}^{3}\end{array}$ & $\begin{array}{c}930 \\
\mathrm{MPa}\end{array}$ & $\begin{array}{c}44 \\
\mathrm{MPa} \\
V_{\mathrm{m}}\end{array}$ \\
\hline
\end{tabular}

Sedangkan data hasil pengujiaa fatigue crack growth pada material Ti6Al-4V yang telah ditunjukkan pada Gambar 2, dapat dibuat garis regresi pada daerah linear (Region 2) seperti ditunjukkan oleh Gambar 3.

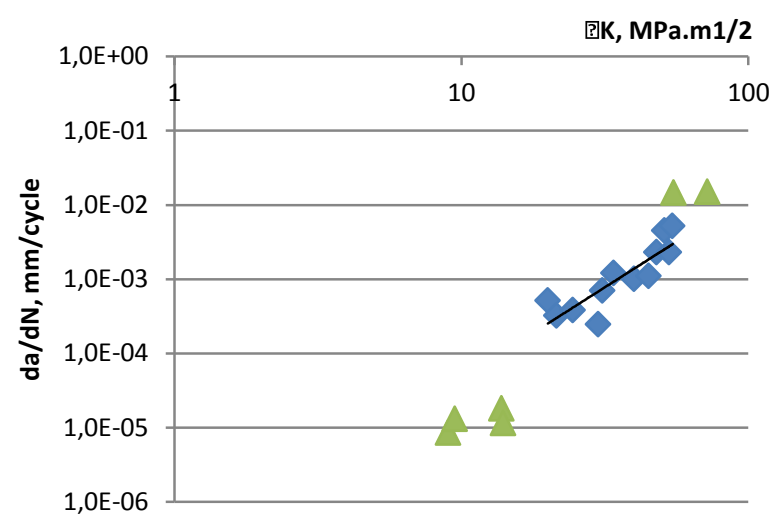

Gambar 3. Garis regresi pada daerah linear (Region II).

Garis regresi ini digunakan untuk mendapatkan persamaan garis seperti ditunjukkan dalam persamaan 1.

$\frac{d a}{d N}=2 \cdot 10^{-7}(\Delta K)^{2.458}$

Persamaan 1 digunakan untuk mendapatkan harga $d a / d N$ untuk setiap harga $\Delta K$ yang berubah terhadap panjang retak.

Dalam permodelan cacat, perlu diperhatikan beberapa hal yang telah ditentukan dalam manual perawatan bilah kipas TAY650-15 khususnya pada bagian yang membahas kasus nicking serta scallop seperti ditunjukkan didalam Gambar 4. 


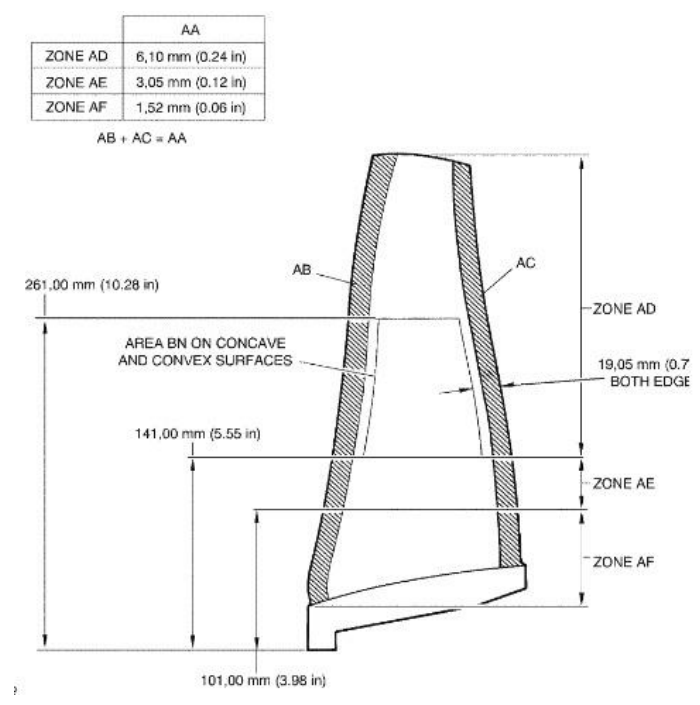

Gambar 4. Pembagian zona bilah kipas mesin TAY650-15

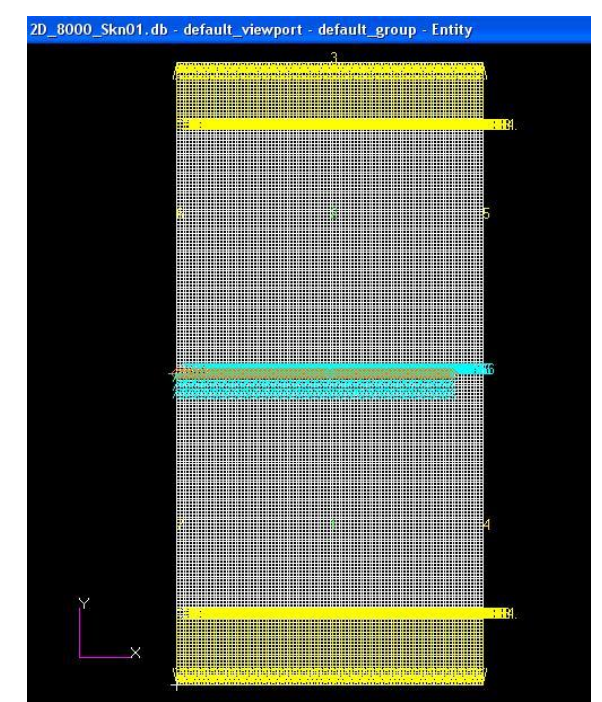

Gambar 5. Model elemen shell 2D

Dalam manual perawatan bilah kipas TAY650-15 daerah bilah kipas dibagi menjadi 3 bagian sebagai berikut:

a. Zona $A F$ : yaitu daerah yang berjarak $0 \mathrm{~mm}$ s.d $101 \mathrm{~mm}$ dari tumpuan.

b. Zona $A E$ : yaitu daerah yang berjarak $101 \mathrm{~mm}$ s.d $141 \mathrm{~mm}$ dari tumpuan

c. Zona $A D$ : yaitu daerah yang berjarak lebih dari $141 \mathrm{~mm}$ dari tumpuan

Setiap zona memiliki batasan toleransi maksimal kedalaman scallop yang diperbolehkan. Dalam tugas akhir ini, retak yang akan dimodelkan terletak pada zona antara $A D$ dan $A E$ yaitu $140 \mathrm{~mm}$ dari Root, seperti ditunjukkan dalam gambar 5.

\section{Model Bilah Kipas 2D}

Model bilah kipas 2D dibuat menggunakan perangkat lunak Patran 2005 dan dianalisis menggunakan Nastran 2005. Model 2D dibuat dengan menggunakan elemen shell empat nodal. Bentuk geometri untuk model 2D berupa pelat persegi panjang dengan ketebalan seragam. Beban pada model 2D di modelkan dengan gaya tarik statik pada kedua ujung atas dan bawah, dan dibotong pada bagian tengah 
untuk diletakkan penumpu, untuk lebih jelasnya lihat Gambar 5.Retak pada model 2D dibuat dengan cara memisahkan nodal pada elemen yang bersebelahan, sehingga membentuk sepasang permukaan retak

\section{Model Bilah Kipas 3D}

Model bilah kipas 3D dibuat menggunakan perangkat lunak Catia V5R18. Bilah kipas dimodelkan dengan elemen solid berbentuk linear tetrahedron mesh. Geometri model 3D memiliki bentuk yang sama dengan geometri bilah kipas sesungguhnya. Geometri model 3D dibuat oleh peneliti sebelumnya dengan menggunakan teknik reverse engineering, yang dilakukan di PT. NTP dengan cara melakukan scanning 3D sehingga mendapatkan point clouds. Setelah mendapatkan point clouds kemudian dibuat outer surface dan akhirnya mendapatkan model solid, seperti ditunjukkan dalam Gambar 6

Untuk model solid 3D, retak dibuat dengan cara membuat cacat yang berbentuk celah yang sangat tipis. Celah tipis ini ditempatkan pada jarak $205 \mathrm{~mm}$ dari pangkal bilah kipas, dengan cacat scallop pada bagian leading edge.
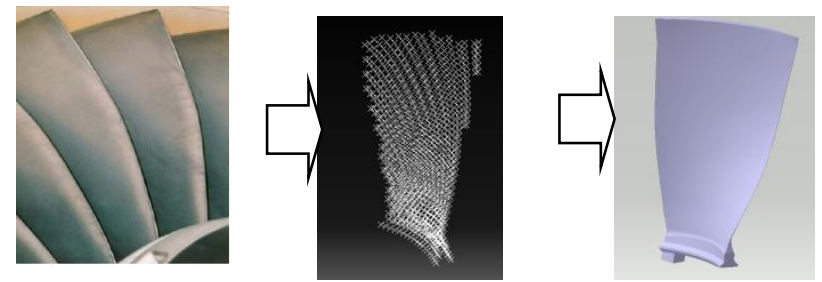

Gambar 6. Pembuatan model kipas 3D

Scallop dimodelkan dengan bentuk setengah ellips seperti ditunjukkan dalam Gambar 7. Cacat scallop dibuat berdasarkan data pada Tabel 2 .

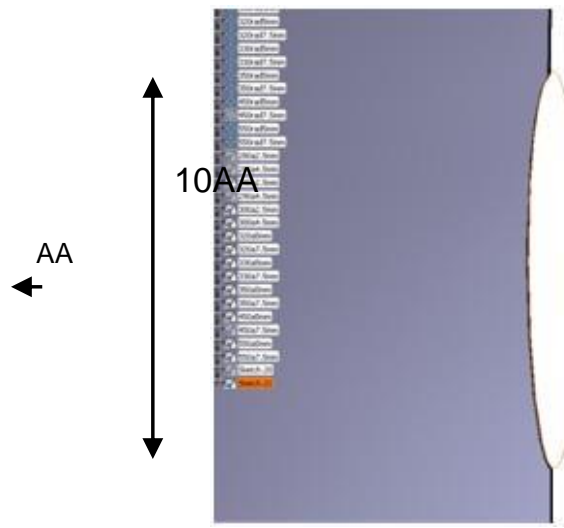

Gambar 7. Model 3D dengan Scalop untuk ukuran $\mathrm{AA}=8 \mathrm{~mm}$

Tabel 2. Data panjang dan kedalaman scallop (dalam mm)

\begin{tabular}{|l|c|c|c|c|}
\hline & AW & AL & AA & $\begin{array}{c}10 \mathrm{~A} \\
\text { A }\end{array}$ \\
\hline $\begin{array}{l}\text { Dalam } \\
\text { Manual }\end{array}$ & 211 & $\begin{array}{c}172.0 \\
7\end{array}$ & 8 & 80 \\
\hline Model & 211 & 170 & 10 & 100 \\
\hline
\end{tabular}


Untuk kedalaman scallop (lebar chord minimum, AL) yang dibuat model adalah kedalaman yang melebihi ketentuan manual, yaitu sebesar $170 \mathrm{~mm}$ (selisih $2 \mathrm{~mm}$ dengan ketentuan dalam manual perawatannya). Hal ini dilakukan dikarenakan permintaan dari PT NTP yang ingin mengetahui hasil analisis jika bilah kipas TAY650-15 memiliki kedalaman scallop diluar ketentuan manual perawatannya yang ditunjukkan dalam Tabel 3 dan Gambar 8.

Beban yang diterima oleh bilah turbin cukup rumit, antara lain beban akibat reaksi dari gaya sentripetal, beban termal dan beban aerodinamika. Pada penelitian ini hanya menggunakan beban akibat reaksi dari gaya sentripetal murni dikarenakan beban ini adalah yang paling dominan. Beban akibat reaksi dari gaya sentripetal adalah beban yang disebabkan adanya gaya akibat reaksi dari gaya sentripetal. Sedangkan gaya akibat reaksi dari gaya sentripetal adalah gaya axial berupa tarik yang disebabkan oleh massa benda tersebut, yang diputar dengan jarak r dari pusat massanya.

Tabel 3. Lebar minimum chord pada setiap daerah dari bilah kipas TAY 650-15

\begin{tabular}{|c|c|c|c|}
\hline $\begin{array}{c}\text { Height } \\
\text { Letter }\end{array}$ & $\begin{array}{c}\text { Section Height } \\
\text { (Gauge) }\end{array}$ & $\begin{array}{c}\text { Chord } \\
\text { Letter }\end{array}$ & $\begin{array}{c}\text { Minimum Chord } \\
\text { Width }\end{array}$ \\
\hline AS & $81,00 \mathrm{~mm}(3.189 \mathrm{in})$ & AG & $174,72 \mathrm{~mm}(6.879 \mathrm{in})$ \\
\hline AT & $101,00 \mathrm{~mm}(3.98 \mathrm{in})$ & AH & $174,65 \mathrm{~mm}(6.876 \mathrm{in})$ \\
\hline AU & $141,00 \mathrm{~mm}(5.55 \mathrm{in})$ & AJ & $173,46 \mathrm{~mm}(6.829 \mathrm{in})$ \\
\hline AV & $161,00 \mathrm{~mm}(6.34 \mathrm{in})$ & AK & $171,13 \mathrm{~mm}(6.737 \mathrm{in})$ \\
\hline AW & $211,00 \mathrm{~mm}(8.31 \mathrm{in})$ & AL & $172,07 \mathrm{~mm}(6.774 \mathrm{in})$ \\
\hline AX & $261,00 \mathrm{~mm}(10.28 \mathrm{in})$ & AM & $173,55 \mathrm{~mm}(6.833 \mathrm{in})$ \\
\hline AY & $311,00 \mathrm{~mm}(12.24 \mathrm{in})$ & AN & $177,13 \mathrm{~mm}(6.974 \mathrm{in})$ \\
\hline AZ & $361,00 \mathrm{~mm}(14.21 \mathrm{in})$ & AP & $184,43 \mathrm{~mm}(7.261 \mathrm{in})$ \\
\hline BA & $401,00 \mathrm{~mm}(15.787 \mathrm{in})$ & AR & $190,75 \mathrm{~mm}(7.510 \mathrm{in})$ \\
\hline
\end{tabular}

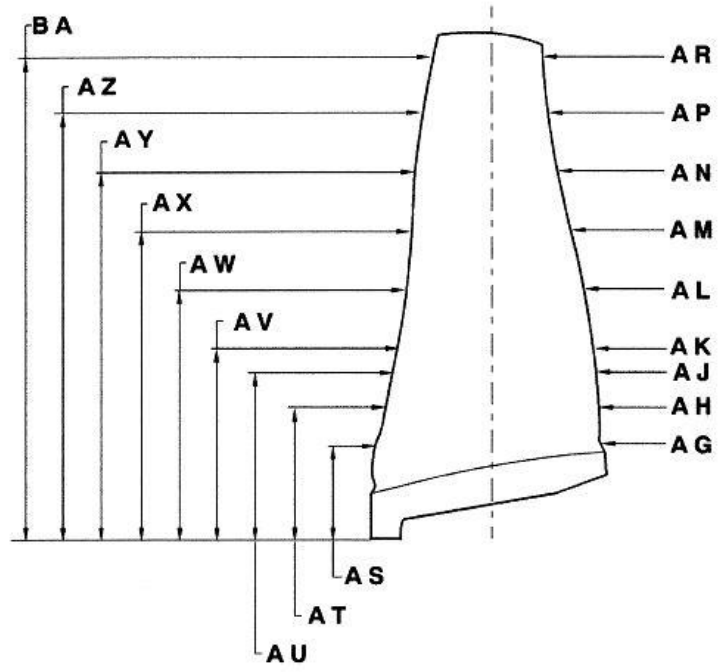

Gambar 8. Panduan Scallop dalam Manual Perawatan TAY650-15

Besarnya beban akibat reaksi dari gaya sentripetal pada model ditentukan dengan cara membagi model menjadi beberapa bagian (dalam hal ini adalah 19 bagian). Model dibagi menjadi beberapa bagian adalah dikarenakan gaya akibat reaksi dari gaya sentripetal adalah merupakan fungsi dari luas 
penampang. Cara menentukan besaran dari beban akibat reaksi dari gaya sentripetal $(F s)$ adalah menurut Persamaan 2 dan Persamaan 3, dengan terlebih dahulu merubah satuan kecepatan sudut dari rpm menjadi rad/s menurut Persamaan 4 dan Persamaan 5.

$\begin{aligned} \omega & =2 \pi f \\ \omega & =2 \pi \frac{n}{T} \\ F_{s} & =\rho \omega^{2} \int_{r}^{t} A r d r \\ F_{s} & =\rho \omega^{2}\left|0.5 A r^{2}\right|_{r}^{t}\end{aligned}$

Keterangan:

$\omega:$ Kecepatan sudut dengan satuan $\mathrm{rad} / \mathrm{sec}$

$n$ : Jumlah putaran dalam satu menit (rpm)

$T$ : Satuan waktu dalam detik

$\rho$ : Masa jenis material

$A$ : Luas penampang

Subscript $r$ : Jarak root terhadap sumbu putar

Subscript $t$ : Jarak tip terhadap sumbu putar

Hasil yang diperoleh dari perhitungan dengan Metode Elemen Hingga menggunakan perangkat lunak MSC Patran-Nastran 2005 adalah berupa Displacement (perpindahan tiap nodal), serta gaya pada Nodal, sedangkan pada CATIA V5R18 hasil yang diperoleh berupa Strain Energy.

Untuk menentukan besaran dari Energy Releasi Rate $(G)$ diperlukan besaran gaya pada nodal sebelum retak membuka, dan perpindahan nodal setelah retak membuka dengan menggunakan Persamaan 6 sampai dengan Persamaan 9.

$$
\begin{aligned}
& G_{I}=-\frac{1}{2 \Delta a} \cdot Z_{i} \cdot\left(w_{l}-w_{l^{*}}\right) \\
& G_{I I}=-\frac{1}{2 \Delta a} \cdot X_{i} \cdot\left(u_{l}-u_{l^{*}}\right) \\
& G_{I I I}=-\frac{1}{2 \Delta A} \cdot Y_{L i} \cdot\left(v_{L l}-v_{L l *}\right) \\
& G_{T}=G_{I}+G_{I I}+G_{I I I}
\end{aligned}
$$

Setelah mendapatkan besarnya $G$, maka selanjutnya Faktor Intensitas Tegangan $(K)$ ditentukan dari perhitungan energi semu yang diperlukan untuk mengatupkan permukaan retak disekitar ujung retak (Virtual Crack Closure technique) menggunakan persamaan 10. Besaran $K$ akan bervariasi terhadap panjang retak.

$K=\sqrt{G_{T} \times E}$

Tegangan pada setiap elemen diperlukan untuk mendapatkan $K_{0}$ yang merupakan komponen yang dibutuhkan dalam menghitung faktor geometri $(\beta)$.

Besarnya tegangan tiap elemen dapat dihitung dengan Persamaan 11.

$\sigma=\frac{F}{A} \quad N / m^{2}$

$K_{0}$ adalah Faktor intensitas tegangan untuk konfigurasi keseluruhan model yang dapat dihitung menggunakan Persamaan 12.

$\mathrm{K}_{0}=\sigma \sqrt{\pi \cdot \mathrm{a}}$

Setelah mendapatkan $K_{0}$ maka selanjutnya adalah menghitung Faktor Geometri $(\beta)$ dengan menggunakan Persamaan 13.

$\beta=\frac{\mathrm{K}}{\mathrm{K}_{0}}$

Kekuatan sisa adalah kemampuan dari model didalam menahan beban yang nilainya akan turun disebabkan oleh pertambahan panjang retak. Jika kekuatan sisa yang ditunjukkan dengan besaran tegangan sudah berada dibawah tegangan operasinya maka struktur akan mengalami kegagalan. Tegangan sisa dapat dihitung menurut Persamaan 14. 
$\sigma=\frac{\mathrm{K}_{\mathrm{C}}}{\beta \cdot \sqrt{\pi \cdot a}}$

$K_{C}$ adalah Fracture Toughnes, dan bilah akan gagal jika didapatkan $K \geq K_{C}$.

Panjang retak kritis $\left(a_{c}\right)$ didapatkan dengan cara membandingkan nilai $K$ untuk panjang retak tertentu dengan nilai $K_{C}$. Jika Nilai $K$ untuk panjang retak tertentu lebih besar atau sama dengan nilai $K_{C}$ maka bilah kipas akan gagal dikarenakan panjang retak sudah mencapai $a_{c}$.

Untuk dapat menghitung umur sisa dari bilah kipas, diperlukan satu data hasil pengujian material berupa $d a / d N$ versus $\Delta K$. Data ini telah ditunjukkan oleh penulis dalam tabel 3.2.

Prosedur yang dilakukan oleh penulis hingga mendapatkan umur sisa dari bilah kipas adalah sebagai berikut:

1. Menghitung $\Delta K$ yang merupakan suatu nilai perubahan $\mathrm{K}$ berdasarkan panjang retak menurut Persamaan 15.

$\Delta K=K_{n}-K_{n-1}$

2. Selanjutnya adalah mendapatkan nilai $d a / d N$ untuk setiap $\Delta K$ yang telah dihitung pada langkah satu dengan menggunakan Persamaan 1.

3. Setelah mendapatkan $d a / d N$ untuk setiap $\Delta K$, selanjutnya adalah menentukan pertambahan panjang retak $(\Delta a)$ menurut Persamaan 16.

$\Delta a=a_{n}-a_{n-1}$

4. Selanjutnya menentukan $\Delta N$ dengan menggunakan Persamaan 17.

$\Delta N=\frac{\Delta a}{d a / d N}$

5. Setelah menghitung $\Delta N$, maka $N$ (umur) dapat dihitung dengan cara menjumlahkan umur awal (0 cycle) dengan $\Delta N$, menurut Persamaan 18 sebagai berikut:

$N_{m}=N_{m-1}+\Delta N$

Pemodelan bilah kipas pada penelitian ini telah dilakukan uji konvergensi untuk mendapatkan jumlah minimum dari elemen yang digunakan. Uji konvergensi pada analisis menggunakan metode elemen hingga bertujuan untuk mendapatkan hasil yang akurat pada jumlah elemen tertentu. Pada uji konvergensi ini suatu kasus dimodelkan dengan jumlah elemen yang berbeda-beda. Semakin tinggi jumlah elemen yang digunakan, maka hasil yang didapatkan akan semakin akurat. Uji konvergensi digunakan untuk mendapatkan hasil yang akurat, dan untuk memilih jumlah elemen paling sedikit yang hasilnya tetap akurat. Pada analisis struktur, jumlah elemen yang sedikit dapat digunakan untuk menganalisis kasus-kasus sederhana dengan akurat. Namun pada kasus analisis struktur dengan geometri dan pembebanan yang kompleks diperlukan jumlah elemen yang banyak untuk mendapatkan pemodelan yang akurat.

Hasil yang didapat dari uji konvergensi untuk model 2D dan solid 3D dapat dilihat dalam Tabel 4.

Tabel 4. Hasil uji konvergensi

\begin{tabular}{|lll|c|}
\hline & & & Jumlah Elemen \\
\hline $\begin{array}{l}\text { Model } \\
\text { scallop }\end{array}$ & 2D & tanpa & 140.000 \\
\hline $\begin{array}{l}\text { Model } \\
\text { scallop }\end{array}$ & 2D & dengan & 230.000 \\
\hline $\begin{array}{l}\text { Model } \\
\text { scallop }\end{array}$ & 3D & dengan & 397.000 \\
\hline
\end{tabular}




\section{HASIL DAN DISKUSI}

Panjang $\mathrm{a}_{\mathrm{c}}$ untuk model 2D tanpa scallop didapatkan sebesar $86 \mathrm{~mm}$ pada harga Faktor Intensitas Tegangan $(K)$ sebesar $44.036 \mathrm{MPa} \sqrt{ } \mathrm{m}$. Panjang retak kritis sebesar $86 \mathrm{~mm}$ didapatkan ketika harga $\mathrm{K}$ mencapai harga Fracture Toughness $\left(\mathrm{K}_{\mathrm{c}}\right)$ dari material Tititanium TI6Al4V sebesar 44.000 .000 $\mathrm{MPa} \sqrt{ } \mathrm{m}$, seperti ditunjukkan dalam Gambar 9.

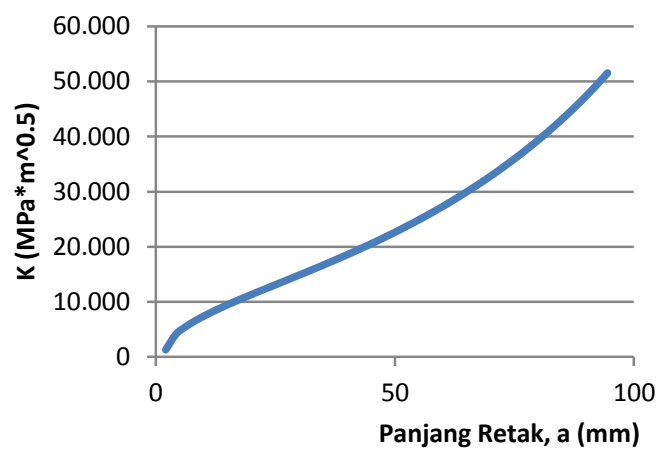

Gambar 9. K versus a pada model 2D dengan scallop

Selain mendapatkan harga $K$ analisis menggunakan Metode Elemen Hingga juga mendapatkan harga faktor geometri $(\beta)$. Faktor geometri $(\beta)$ didapatkan dari perbandingan $K$ terhadap $K_{0}$. Grafik $\beta$ terhadap $a / b$ dapat dilihat dalam Gambar 10. Notasi $a / b$ adalah perbandingan panjang retak $a \mathrm{~mm}$ dengan lebar dari bilah kipas $b \mathrm{~mm}$.

Grafik $\beta$ dalam gambar 10 menjelaskan nilai yang didapat dari perhitungan MEH dan nilai yang diambil dari data hand book. Tampak bahwa nilai keduanya hampir berhimpit dengan perbedaan sekitar 3\%.

Berbeda dengan model 2D tanpa scalop, model dengan scallop memiliki panjang retak kritis yang lebih pendek yaitu sebesar $80 \mathrm{~mm}$ dengan Faktor Intensitas Tegangan (K) sebesar $44.813 \mathrm{MPa} \sqrt{\mathrm{m}}$, seperti ditunjukkan dalam Gambar 11. Sedangkan grafik $\beta$ terhadap $a / b$ untuk model 2D dengan scallop ditunjukkan dalam Gambar 12. Jadi model 2D dengan scallop memiliki panjang retak kritis yang lebih pendek dari pada model 2D tanpa scallop, sehingga scallop mempengaruhi panjang retak kritis.

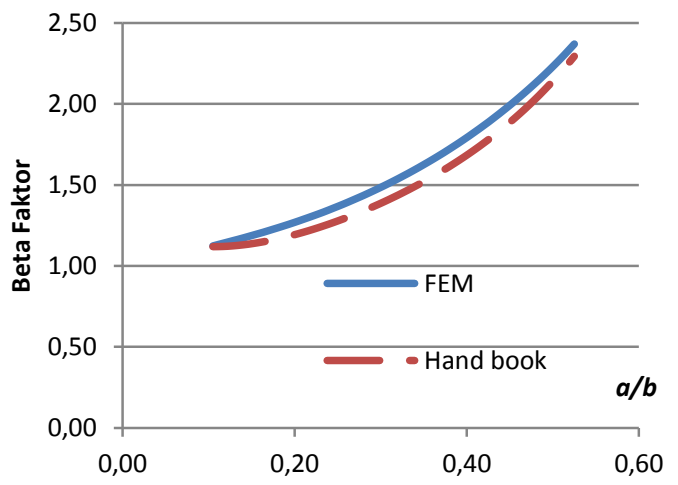

Gambar 10. Grafik $\beta$ terhadap a/b untuk model 2D tanpa scallop yang didapat dari metode Numerik dan Hand book 


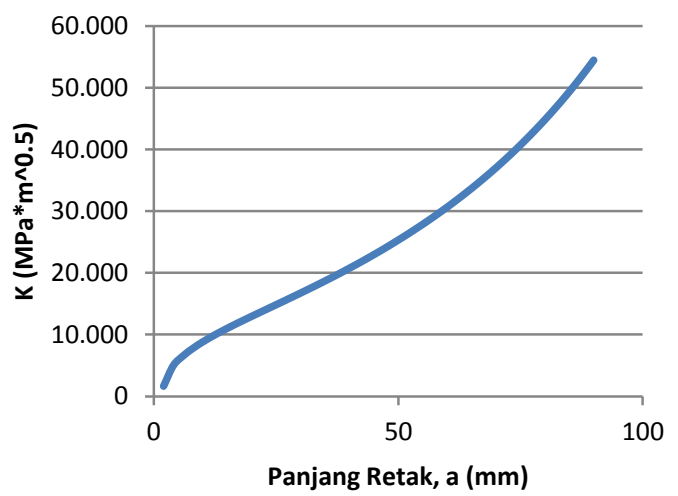

Gambar 11. Grafik K versus panjang retak untuk model 2D dengan scallop

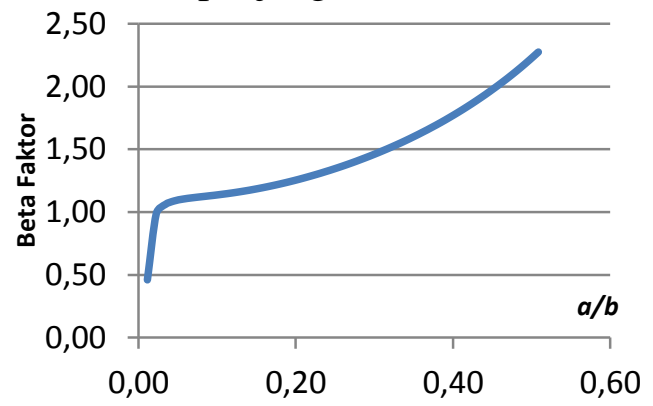

Gambar 12. Grafik Faktor geometri $(\beta)$ terhadap a/b untuk model 2D dengan scallop

Retak kritis yang didapatkan pada model solid 3D adalah sebesar $92 \mathrm{~mm}$ dengan Faktor Intrensitas Tegangan (K) sebesar 44,9 MPa $\sqrt{\mathrm{m}}$, seperti ditunjukkan dalam Gambar 13. Model solid 3D dengan scallop memiliki nilai dari panjang retak kritis terbesar dibandingkan dengan model 2D tanpa dan dengan scallop. Grafik $\beta$ terhadap $a / b$ ditunjukkan dalam Gambar 14

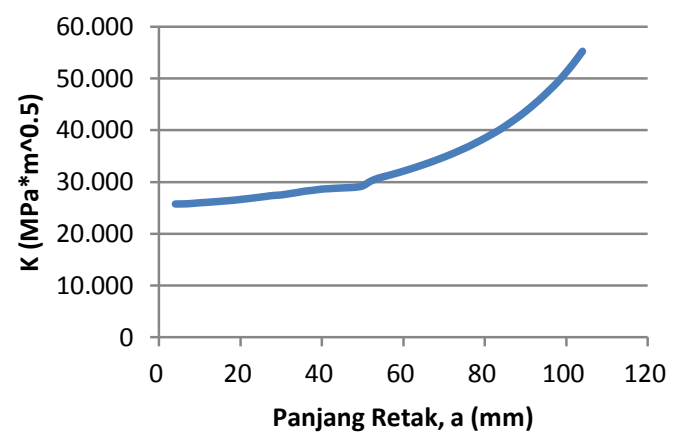

Gambar 13. Grafik K versus panjang retak untuk model solid 3D dengan scallop 


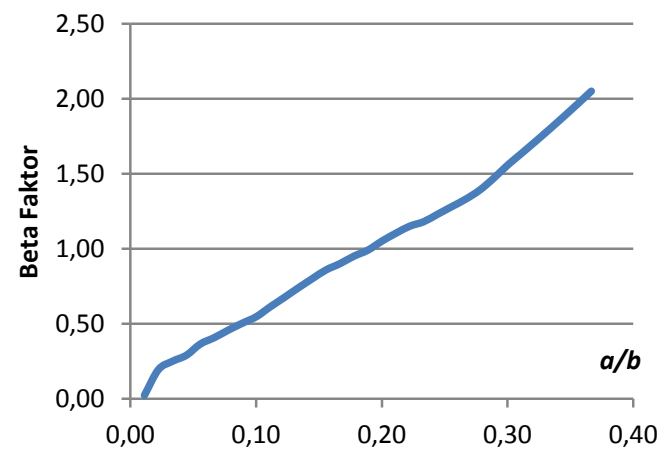

Gambar 14. Grafik faktor geometri $(\beta)$ terhadap a/b untuk model solid 3D dengan scallop

Umur bilah kipas saat mencapai $a_{c}$ untuk model 2D tanpa scallop adalah 21.700 cycle, seperti ditunjukkan dalam Gambar 15. Untuk model 2D dengan scallop umur bilah kipas saat mencapai $a_{c}$ adalah 17.600 cycle, seperti ditunjukkan oleh Gambar 16. Dan untuk model solid 3D dengan scallop umur bilah kipas saat mencapai $a_{c}$ adalah 16.300 cycle, seperti ditunjukkan dalam Gambar 17. Umur design goals bilah kipas tanpa retak menurut data dari PT. NTP adalah sebesar 20.000 cycle.

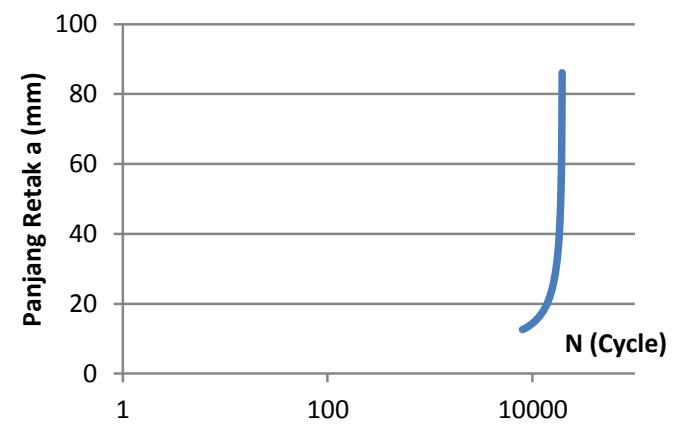

Gambar 15. Grafik a versus N model 2D tanpa scallop

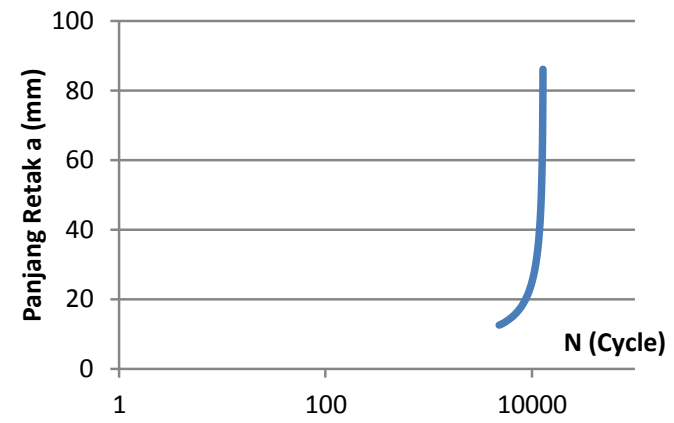

Gambar 16. Grafik a versus $\mathrm{N}$ model 2D dengan scallop 


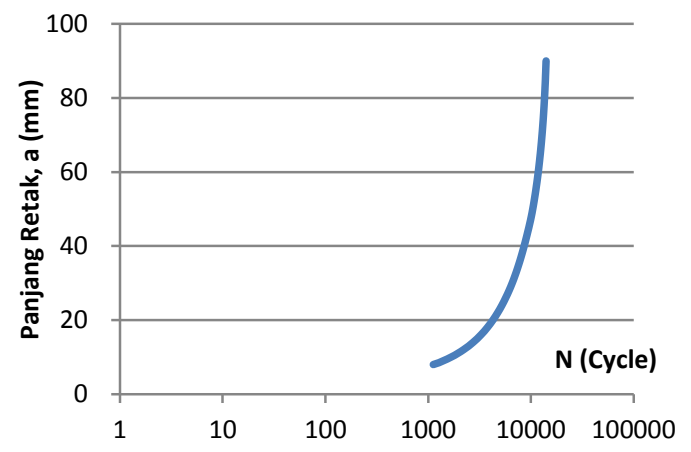

Gambar 17. Grafik a versus $\mathrm{N}$ model 3D dengan scallop

\section{KESIMPULAN}

Metode Elemen Hingga dan Teori Virtual Crack Closure dapat digunakan untuk menghitung Faktor Intensitas Tegangan $(K)$ dan Faktor Geometri $(\beta)$ sebagai metode Numerik disamping menggunakan data pada Hand Book. Model 2D dengan scallop akan memiliki $a_{c}$ yang lebih pendek dari pada model 2D tanpa scallop.

Tindakan perbaikan dengan kedalaman scallop yang melebihi ketentuan dari pabrik dalam Repair Manual akan menyebabkan umur bilah kipas akan lebih pendek sekitar 5.043 cycle dibandingkan dengan umur yang ditentukan oleh pabrik yaitu 20.00 cycle.

Untuk penelitian selanjutnya terdapat beberapa saran diantaranya adalah beban yang digunakan adalah beban pada kondisi sebenarnya, yaitu memperhitungkan juga beban akibat gaya aerodinamika. Selanjutnya analisis struktur bilah kipas pada bagian tumpuan (support) karena daerah ini merupakan daerah yang menerima beban paling tinggi. Disarankan juga untuk menggunakan data material properties sesuai dengan spesifikasi pabrik pembuat. Untuk mendapatkan $G$ (Laju Pelepasan Energi) yang akurat makad disarankan untuk menggunakan $G$ total $\left(G_{T}\right)$ yang didapatkan dari penjumlahan $G_{I}$, $G_{I I}$, dan $G_{I I I}$ pada modus I, II dan III untuk model solid 3D.

\section{DAFTAR PUSTAKA}

ARISMUNANDAR, WIRANTO, Pengantar Turbin Gas dan Mesin Propulsi, Penerbit ITB, Bandung, 2002

KNIGHT, CHARLES E., The Finite Element Method in Mecanical Design, PWS-KENT Publishing Company, Boston, 1993

PICKARD, A.C., ROLL-ROICE LTD., The Application of 3-Dimensional Finite Element Methods to Fracture Mechanics and Fatigue Life Prediction, The Chameleon Press LTD, London, 1986

HERTZBERG, RICHARD W. (1995-12). Deformation and Fracture Mechanics of Engineering Materials (4 ed.). Wiley. ISBN 0471012149.

Edited by MATTHEW J. DONACHIE, JR., Metals Handbook, Ninth edition, Volume 3. Properties and selection: Stainless Steel. Tool Materials and Special-Purpose Metals. The Hartford Graduate Center

ANDERSON, t.l, Fracture Mechanics - Fundamental and Aplications, CRC Press Inc., U.S.A., 2000

PUTRA, ICHSAN S., Diktat Kuliah Damage Tolerance Analysis. Institut Teknologi Bandung, 2004

CRAIG, ROY R. JR., John Wiley \& Sons, Mechanics of Materials, Canada, 1996.

E.F.RYBICAKNI DM.F.KANNINEAN, Finite Element Calculation of Stress Intensity Factors by a Modified Crack Closure Integral, Eng. Fracture Mech., Vol. 9, pp. 931-938, 1977.

INGRAFFEA AND P. WAWRZYNEK, FRANC2D: A Case Study in Transfer of Software Technology, in Research Transformed into Practice: Implementations of NSF Research, J. Colville and A. Amde, Eds.: ASCE Press, New York, 1995, pp. 233-344. 